\title{
Analýza vývoje vnímání národní identity německou CDU v letech 1990-2009
}

\author{
Michal Vít ${ }^{1}$
}

\begin{abstract}
Analysis of the Development of the CDU's Perception of National Identity Between 1990 and 2009
The paper aims to explain the development of the perception of national identity of the Christian Democratic Party (CDU), the strongest German political party in the past few decades. The paper focuses on election manifestos for the 1990, 1994, 1998, 2002, 2005, and 2009 elections. For this purpose, each manifesto is examined according to up to five analytical categories - such as values, nation, Europe, threats, and society. These categories explore the party's perception in a wider context instead of focusing only on direct references to national identity. The analysed period was divided into three phases with an emphasis on the internal crisis between the years 1998 and 2002. The crisis influenced policy priorities; therefore the perceptions of elements belonging to national identity were changed in order i) to gain victory in the general elections in 2002 and 2005, and ii) to reflect properly the state of German society. Therefore, significant policy shifts were made. These policy changes show how the party successfully integrated societal demands and preferences over the past decade. Thank to this, the CDU incorporated both conservative and liberal elements. This is evident in the case of incorporating liberal elements such as homosexual partnerships while, at the same time, actively stressing the importance of defending national interests.
\end{abstract}

Keywords: CDU, national identity, European integration, political parties

\section{1. Úvod}

Formování postojů Christlich Demokratische Union (CDU) v otázkách spojených s percepcí národní/evropské identity prošlo v uplynulých 20 letech výraznou proměnou. Tato skutečnost se netýká pouze výhradně CDU, ale ve větši či menší míre všech relevantních politických stran $\mathrm{v}$ rámci německého politického systému. Cílem textu je analytický pohled na proměňující se př́stup CDU ke zmíněným fenoménům $\mathrm{v}$ uplynulých 20 letech ${ }^{2}$ aplikováním konceptu path dependency. Základním předpokladem tohoto konceptu je souvislost po sobě následujících událostí. Nelze vnímat určitý okamžik jako samostatný fenomén, ale je nutné vzít v potaz čas, motivaci a prostor události. V kontextu zkoumání institucí koncept path dependency zahrnuje také jejich pravidla, normy a ideje, které utváŕejí sociální interakce instituce (Ebbinghaus 2005:6). Dle Piersona $(2000$, 2004) je prvotním hybatelem změny struktury, nebo institucionálního nastavení, krizový moment (critical juncture), který v závislosti na kontextu situace způsobí již zmíněnou změnu. Pro účely zkoumání vývoje vnímání národních percepcí CDU jsem časové období rozdělil do následujících úseků: 1990-1998; 1998-2002; 2002-2009. Pozornost bude věnována zejména období 1998-2002, kdy CDU jakožto opoziční strana čelila ekonomickým problémům Německa, zásadní redefinici německé integrační politiky a v poslední řadě také $\mathrm{v}$ tomto období CDU zaznamenala dvě po sobě jdoucí volební porážky od sociální demokracie. Vycházeje z konceptu path dependency, text se zaměřuje na proměnu vnímání národních percepcí CDU z perspektivy definovaných kriæí, nebo spíše momentů, reagujících na proměnu vnějšího prostředí a jejich následnou reflexi ve volebních programech.

Cílem textu je odpovědět na následující výzkumné otázky:

\footnotetext{
${ }^{1}$ Interní doktorand na Katedře mezinárodních vztahů a evropských studií, Masarykova univerzita, a na Institut für Politikwissenschaften Universität Leipzig; kontakt: vit.michal@yahoo.com

${ }^{2}$ Jmenovitě za voleb do Spolkového sněmu v letech 1990, 1994, 1998, 2002, 2005 a 2009
} 
i) Jak ovlivnilo krizové období formování národní identity CDU - zda došlo k zásadní redefinici vnímání národní identity, či zda lze vysledovat postupný vývoj bez ohledu na krizové období?

ii) Vezmeme-li v potaz volební vítězství v letech 2005 a 2009, lze předpokládat, že překlenutí krizového období proběhlo úspěšně. Lze $\mathrm{v}$ analyzovaném období vysledovat dlouhodobé trendy proměny širšího kontextu než byla proměna v letech 1998-2002?

Úvodní část textu shrnuje reflexi zkoumání národní identity v německém prostředí a představení konceptu path dependency. Následující kapitola nabízí stručný vhled do formování německé evropské politiky v kontextu poválečného evropského dědictví Konrada Adenauera, po níž v jednotlivých časových obdobích následuje analýza volebních programů, ve které se zaměřuji na následující oblasti: Evropa, národ, hodnoty, společnost a hrozby. Na jejich základě jsou zkoumány volební programy. Vlastní analýza postupuje chronologicky po jednotlivých volebních programech podle stanovených kategorií. V závěru shrnuji tendence vývoje vnímání národních a hodnotových priorit a pomocí konceptu path dependency se pokouším odpovědět na otázky zachycující dlouhodobou dynamiku vývoje.

\section{Reflexe výzkumu problematiky národní identity}

Výzkum formování národní identity politických stran se v německém prostředí netěší př́lišs velké pozornosti. Tématu vývoje národní a evropské identity se intenzivně věnoval např. Thomas Risse (2002, 2007, 2010). Z hlediska strategické kultury a jejího přesahu do německé zahraniční politiky německou národní identitu zkoumal Hans Maul (2002, 2007). V obecném kontextu se formováním národní a evropské identity dlouhodobě zabývá nestor současné německé filozofie Jürgen Habermas $(2006,2010)$, jenž se soustředí na koexistenci nadnárodní společenské struktury s národní. Tématu vnímání a formování identity ve společnosti se v německém prostředí věnuje nap̌r. Jörg Zirfas (2010). Společným bodem těchto prací je velmi zdrženlivý př́stup $\mathrm{k}$ problematice vztahu národní identity a politických stran, resp. to, jakým způsobem strany formují své pojetí národní identity. Je třeba uvést, že právě proto text zachycuje relativně dlouhé období tak, aby bylo možné obsáhnout dlouhodobé vlivy působící na politické strany a společnost obecně: z pozice ohrožení politických stran populistickými tendencemi (Lochoki 2012; Decker 2007); politicko-filozofickým prrístupem zaměřujícím se na utváření společenského kontextu (Hacke 2006); vývojem pojetí evropské politiky politickými stranami, kterým se zabývá např. Gisela Müller (2007). Velmi zdařilou analýzu německé historické paměti a její přesah do formování společenského prostředí nabízí analýza Miroslava Kunštáta (2011). Ten se věnuje významným soudobým momentům a jejich transkripci do obecného (národního) povědomí.

Je zřejmé, že reflexe národní identity - obzvláště politických stran - není populárním předmětem výzkumu. Text neusiluje o normativní konstatování směřující k odsouzení/podpoře utváření identity politickými stranami, ale považuje skutečnost, že politické strany a společnost jsou ve vzájemné interakci, za daný fakt. Z tohoto pohledu je zřejmé, že i přes absenci deklarované snahy o ovlivňování společenského diskursu politickými stranami tento proces probíhá přirozeně. Použitím konceptu path dependency se otevírá prostor pro analýzu zaměřenou na sledování proměňujícího se formování národní identity nikoli na základě zkoumání narativu národní identity, ale zapojením rámce zkoumajícího proměnu identity. Z tohoto důvodu se text 
zaměřje zejména na proměňující se formování identity, nikoli na normativní hodnocení konceptu identity v prŕpadě CDU.

\section{a. Koncept path dependency}

Výše zmíněný prístup ke zkoumání sociálního prostředí - zejména institucí - se v sociálních a ekonomických vědách stal v poslední době značně populárním. Ačkoli se velmi často používá ke zkoumání institucionálních změn nebo celého institucionálního rámce určitého prostředí, níže uvedený prŕklad Bruna Pailera ukazuje možnosti aplikace path dependency k výzkumu změn $\mathrm{v}$ oblasti policy. V tomto př́padě jsem se pokusil použít zmíněný koncept na méně snadno uchopitelnou oblast policy - národní identitu. Stejně tak použití volebních programů není typickým podkladem pro použití konceptu path dependency. Nicméně volební programy souměřitelně zachycují vývoj vnímání zkoumaných tendencí a jsou široce považovány za relevantní zdroj dat o vývoji politických stran. Zjednodušeně lze př́stup definovat chápáním budoucích událostí na základě událostí minulých, kdy historie hraje zásadní roli pro pochopení změny/události. Koncept nechápe vývoj prostředí lineárně, ale na základě tzv. rostoucích výnosů (increasing returns). Dủležitou roli zastává také časová dimenze, nebot' správné načasování změny přináší instituci komparativní výhodu v rámci prostředí (Ebbinghaus 2005; Fetzer 2009).

Analytický př́stup $\mathrm{k}$ path dependency lze rozdělit na dvě části: deterministickou a krizovou (road juncture). Deterministický způsob klade důraz na vliv prostředí, resp. ostatních aktérů, kteř́ ovlivňují aktéra postaveného před nutnost volby do té míry, že při výběru postupu se řídí ostatními aktéry. Ebbinghaus (2005: 6) tento koncept nazývá „vyšlapaná cesta“ - aktér podléhá vlivu prostředí a tím znemožňuje zásadní zvrat nebo nový impuls ve vývoji. Systém, ve kterém se aktéŕi pohybují, je zpravidla uzavřený a nabízí velmi omezené možnosti pro jeho proměnu. $\mathrm{Z}$ tohoto pohledu je systém velmi neefektivní $\mathrm{k}$ prosazení změny. Ty musí probíhat současně s co největším počtem aktérů, aby došlo $\mathrm{k}$ dlouhodobému přežití instituce. Tento prŕstup může vysvětlit spíše procesy s dlouhou časovou perspektivou neaspirující na zásadní redefinici systému. Druhý koncept klade ve větší míře důraz na samostatnost zvoleného řešení aktéra. Zvolený způsob může obsahovat inovativní prvek, který způsobí proměnu (vnitřního) prostředí aktéra.

Široký konceptuální rámec nabízí Paul Pierson (2000, 2004), který chápe závislý historický a/nebo časový proces jako souslednost sebe posilujících událostí. Právě souslednost považuje Pierson za zásadní, nebot' i událost malého významu může podnítit další změny. Bez př́hodného načasování a bez minulé souvislosti by událost nedosáhla natolik zásadního dopadu. Zároveň je proces ve své počáteční fázi - Pierson ji definuje jako již zmiňovanou krizi - otevřen novým vlivům. Systém se s postupujícím časem stává uzavřenějším, a zaměřuje se na partikulární proměnu (Pierson 2000: 77). Koncept zahrnuje tři základní fáze - v první dochází ke krizovému okamžiku, který vytváří prostor pro reakci/změnu prostř́edí; v druhé fázi se utváří reakce na událost a rozhodnutí pro výběr řešení; v konečné, třetí fázi pak reakce naruší dosavadní rovnováhu. V Piersonově chápání je základním bodem změna (critical juncture), která se nachází na počátku i na konci procesu. Mahoney (2000) k této argumentaci dodává, že krizová událost v pojetí path dependency vyvolává řetězec vzájemně souvisejících událostí, které nemohou být vysvětleny bez řádného uchopení kontextu události.

Při aplikování konceptu path dependency na institucionální aktéry Pierson dospívá k závěru, že krizové momenty pozitivně přispívají $\mathrm{k}$ vývoji institucí tím, že pozitivní zpětná vazba vytvárí prostor pro zvětšování vlivu instituce (increasing returns). V této souvislosti definuje tři možné způsoby postupu: zásadní počáteční změna, která vyžaduje dlouhodobé nasazení instituce 
k návratu počáteční investice; druhou možností jsou tzv. učební efekty, při kterých instituce více vychází ze svých zkušeností; nebo zaměřením se na partikulární cíle nemající za cíl změnu struktury instituce.

Naopak Pailer (2008: 28-30) na príkladu reforem kontinentálních sociálních systémů argumentuje, že i ke změně politiky nemusí dojít nutně na základě krizového vývoje vyvolávajíć́ho nutnou změnu. Pailer uvádí, že krizový okamžik je sice vhodnou záminkou pro uskutečnění reforem/změn, nicméně se nejedná o podmínku zásadní. Dle něj je naopak nezbytné brát dostatečně v potaz dlouhodobý vývoj. Pailer (2008: 29) uvádí, že méně významné změny (nejnižší úroveň změn) nenaruší institucionální strukturu z důvodu spětí s minulou zkušeností, ale způsobí změnu vnitřního uspořádání priorit. Druhou úrovní je vytvoření nových policy instrumentů reagujících na změnu prostředí. Vnímání národní identity lze označit za oblast, která nepodléhá nutnosti akutní (paradigmatické) změny. Toto schéma lze vztáhnout na problematiku výzkumu politických stran, kdy první úroveň způsobí změnu programových priorit v návaznosti na priority obsažené $\mathrm{v}$ minulých programech. Druhá úroveň pak znamená zásadní změnu minulých priorit a současně nové instrumenty (policy priority). V souvislosti se zkoumáním formování národní identity je třeba zmínit, že tato oblast zpravidla nepodléhá dramatickému vývoji, tedy v tomto konkrétním př́padě i přes definované krizové období CDU. Vzhledem k tomu, že se soustředím na zachycení vývoje ve volebních programech, a nikoli na institucionální proměny, lze tento koncept vztáhnout na proměnu programových priorit uvedených v programech. První úroveň lze vztáhnout na změnu struktury priorit, druhou úroveň na nové programové body v kontextu vývoje prostředí, ve kterém se strana pohybuje.

Ačkoli výzkumy pracující s konceptem path dependency jej aplikují spíše na rovinu policy na národní úrovni (prípadně v komparativní perspektivě) či na dynamiku vývoje institucí, path dependency představuje vhodný nástroj i pro analýzu politických stran. $\mathrm{V}$ tomto př́padě se soustředím na proměnu roviny policy CDU v oblasti formování národní identity. Mưže se zdát, že problematika národních percepcí je př́liš fluidní fenomén. Avšak na rozdíl od prakticky orientovaných politik vnímání národní identity zachycuje hlubší procesy probíhající v politické straně. Jedná se o reflexi proměňujícího se vnějšśho prostř̌edí (požadující např. liberalizaci německé imigrační politiky) a vnitřních problémů (prohrané volby v letech 1998 a 2002, hledání nové vůdčí osobnosti). Právě analýza těchto procesů pomocí konceptu path dependency nabízí ucelený rámec, jak nahlížet na vývoj nejdůležitější německé politické strany.

\section{b. Výzkumný postup}

Analýza volebních programů byla provedena kvalitativní metodou, jejímž cílem nebylo počítání frekvence zmínění hledaných pojmů, ale celkový kontext a vyznění sdělení zkoumaných témat. Nelze se soustředit pouze na mechanické analyzování jednotlivých pojmů, ale na celkové „poselství volebních programů. Politické strany ve svých programech odrážejí rozložení společnosti a ve volebních programech na tuto skutečnost patřičně reagují. Na tomto stavu společnosti zpravidla politické strany definují nejdůležitější hodnotové pilî́re strany, které se zároveň mezi jednotlivými volebními periodami proměňuje. Hlavním cílem je zachycení dlouhodobého vývoje národních percepcí a hodnotového ukotvení. Percepce je nutné vnímat jako formu odezvy, resp. reakce politických stran ( $v$ tomto př́padě CDU) na určité společenské prostředí v jednotlivých volebních obdobích - jak reagují na společenské problémy a jak je následně transformují do volebních programů; jakým způsobem vsazují tyto hodnotové priority do kontextu „reálné politiky“. Volební programy slouží nejen k artikulaci témat, kterými se 
politické strany pokouší zaujmout voliče, ale také zachycují reflexi stavu společnosti. Děje se tak $\mathrm{v}$ částech zachycujících hodnoty a ideové ukotvení strany (zpravidla preambule), ale i v částech reflektujících jednotlivé politické oblasti.

Do analýzy jsem nezahrnul dokumenty zabývající se dlouhodobým směřováním politických stran, a to $z$ důvodu menšího důrazu na snahu o zaujmutí voličů, s čímž souvisí primární koncentrace na stranické hodnotové priority. Z důvodu případného rozmělnění analýzy jsem do práce nezahrnul programy pro volby do Evropského parlamentu, ale soustředil jsem se na genezi percepcí v rámci národních volebních programů.

Při analýze volebních programů jsem se zaměřil na definování a vnímání následujících fenoménů: percepci pojmů národ ${ }^{3}$ a stát jako takové, snahu o definování teritoriální a společenské jednoty země, př́stup $\mathrm{k}$ národnostním menšinám, resp. $\mathrm{k}$ integraci menšin $\mathrm{v}$ Německu, postoj k prohlubování integrace EU (jednotlivé smluvní revize ES/EU, zavedení jednotné měny euro).

V textu často operuji s termínem evropská/národní, resp. společenská identita země. Jak vyplývá z výše uvedeného odstavce, těmito termíny rozumím př́islušnost jedince/občana ke společnému celku, tedy $\mathrm{v}$ prrípadě politické strany se jedná o definování vztahu jedince se sdíleným (politickým) celkem. Jedná se o vyjádření vztahu politické strany vůči společenskému a politickému systému, uchopení a definování národní a evropské jednoty. Dále v tomto procesu spatřit definování hodnotového směřování společnosti (resp. státního útvaru) a komunikace s občany/voliči.

\section{Analýza volebních programů}

V následující části se budu podrobně chronologicky věnovat jednotlivým volebním programům. Analýza každého z šesti volebních programů je doplněna tabulkou znázorňující detailní kategorizaci pro každý volební program a pro přehledné rozčlenění politických priorit. Rozdělení do tematických kategorií tak je dobrým vodítkem pro schematické sledování vývoje strany $\mathrm{v}$ jednotlivých kategoriích, př́padně vzniku zcela nové kategorie. Rozdělení percepcí a politických kroků bylo rozděleno do následujících částí:

- Evropa: vnímání integrace EU, prohlubování institutu evropského občanství, jednotlivé politické kroky ovlivňující prohloubení př́padně zvolnění nadnárodní integrace a projekce německého pohledu na evropskou integraci, respektive přenos německých priorit na úroveň EU.

- Národ: jak strana chápe jednotu a celistvost státu, př́stup k integraci migrantů žijících v Německu, vztah s etnickými Němci ve státech bývalého východního bloku a postoj k získání německého občanství.

- Hodnoty: jak politická strana chápe svou roli ve zprostředkování hodnotového systému mezi jedincem a společností, jaké jsou hodnoty zastávané politickou stranou a jak strana chápe prosazování těchto hodnot v rámci společenského uspořádání.

Mimo výše uvedené tři kategorie jsem definoval další dvě minoritní kategorie, které reprezentují rozdílný př́stup zejména ke kategoriím bodnoty a národ. Pro lepši přehlednost $\mathrm{v}$ analýze jednotlivých programů jsem se rozhodl pro preciznější rožrazení zkoumaných

\footnotetext{
${ }^{3}$ Bliže ke konceptualizaci pojmů národ a stát ve vztahu k politickým stranám Breuilly 1993; Schöpflin 2000; Castells
} 2010 . 
percepcí. Tyto kategorie jsou prrítomny pouze u některých volebních programů, jejich plošné zařazení by mohlo vést $\mathrm{k}$ vágním poznatkům.

- Hrozby: jak strana definuje společensky nebezpečné jevy ohrožující společenskou integritu země.

- Společnost: vnímání společnosti jako základního prvku v hodnotovém uspořádání země.

\section{a. Období 1990-1998, analýza volebních programů}

\section{Kontext nèmecké politiky po roce 1989}

Pád Berlínské zdi znamenající (možné) sjednocení Německa nebyl pro tehdejšího kancléře Helmuta Kohla automatickou samožrejmostí. Z tohoto pohledu je zajímavé sledovat, jak záhy po pádu zdi došlo k nastolení tématu sjednocení jako hlavní priority tehdejšího politického diskursu a jak došlo k projekci témat sjednocení Německa do volebních programů pro volby do Spolkového sněmu. Ve stejné době probíhající vyjednávání o podobě Smlouvy o EU, z něhož vyplynul mimo jiné institut evropského občanství, znamenala spojení dvou významných procesů formující společenskou a politickou identitu Německa. Na jedné straně snaha o uchopení jednoty Německa za situace, kdy Spolková republika Německo (SRN) a Německá demokratická republika (NDR) se nacházely v diametrálně rozdílné politické, společenské a ekonomické situaci, a důraz na podporu evropské integrace na straně druhé. Prosazování těchto cílů je zajímavé sledovat také za situace, kdy se po otevření spolupráce se státy východního bloku naskytla možnost navázání kontaktu s německými menšinami v zahraniční.

CDU byla zejména v první polovině 90. let rozkročena mezi dvěma na první pohled protichůdnými procesy - silnou podporou evropské integrace a podporou německých menšin v zahraniční ve formě podpory sestěhování (návratu) do Německa. ${ }^{4} \mathrm{Na}$ počátku 90 . let lze CDU spatřit jako nejvýraznější politickou sílu podporující prohloubení a rozšíření nadnárodní integrace EU (Scheuer, Schmitt: 2009: 583). Byl to právě Helmut Kohl, kdo v průběhu vyjednávání Smlouvy o EU spojil německou budoucnost v EU tak silně, že přijetí společné měny označil následovně: Euro je otázkou války, nebo míru (Banchoff 1999: 174). ${ }^{5}$ Lze namítnout, že v německém prostředí panuje silný poválečný konsensus $\mathrm{v}$ otázce podpory evropské integrace, a tudíž není nutné brát Kohlovu roli za stěžejní, nicméně právě jeho role, respektive role CDU, byla pro formování tohoto dominantního politického př́stupu zcela zásadní. ${ }^{6}$

Upozad'ující role křest’anských hodnot $\mathrm{v}$ německé a celkově západoevropské společnosti znamenala $\mathrm{v}$ prrípadě CDU otázku, jak transformovat svou křest’anskou tradici ve smyslu definice a prosazování hodnot. ${ }^{7}$ Proces sekularizace společnosti nabyl na intenzitě na počátku 90 . let. Zároveň došlo k rozpadu východního bloku a konzervativní část politického spektra ztratila jeden za svých argumentů pro prosazování hodnot křest’ansko-demokratické politiky.

\section{Volebni program 1990}

Volby do Spolkového sněmu konané v prosinci 1990 byly prvními volbami znovusjednoceného Německa. Volební program pro tyto volby byl utvářen $\mathrm{v}$ době, kdy probíhalo vyjednávání o

\footnotetext{
${ }^{4}$ Je třeba uvést, že zmínka o navázání vztahů s etnickými Němci žijícími v zahraničí byla ve volebních programech prítomna již dříve.

${ }^{5}$ Blíže k definování německé (integrační) identity např. Baumann (2007), Risse (2007) nebo Maull (2007).

6 Jak uvádí Jens Hacke (2006:28), ukotvení integračního imperativu do politického a společenského smýšlení Německa bylo součástí o liberálně-konzervativní ukotvení politického směřování Kohlovy éry v čele země.

${ }^{7}$ Blíže ke genezi vztahu křest’anských hodnot a CDU např. Zolleis 2003, 2008 nebo Pickel 2011.
} 
sjednocení země, a Německu se otevřela cesta k navázání kontaktu se sousedními státy na demokratické bázi v regionu strední a východní Evropy. Tyto události, které byly v době konání voleb prakticky pouze rok staré, znamenaly pro CDU nutnost rychlého jednání a vytvoření nejen politických nástrojů, ale hlavně společného rámce pro národní jednotu. Vezmeme-li tyto události v kontextu vyjednávání Smlouvy o EU na úrovni ES, nabízí se velmi pozoruhodný pohled na př́stup CDU k národní/evropské identitě. Ukazuje se, jak byl př́stup CDU v zásadě rozkročený, či spíše nejednotný.

Tabulka č. 1: Přehled priorit volebního programu v roce 1990

\begin{tabular}{|c|c|c|c|c|}
\hline Volební & \multicolumn{4}{|c|}{ Analytická kategorie } \\
\hline 1990 & Evropa & Svět & Národ & Hodnoty \\
\hline & $\begin{array}{l}\text { Podpora nadnárodní } \\
\text { integrace a } \\
\text { upozadění } \\
\text { národních zájmů; } \\
\text { integrace jako } \\
\text { smíření kultur } \\
\text { v Evropě }\end{array}$ & $\begin{array}{l}\text { Podpora volného trhu } \\
\text { v rámci ES a ve světě; } \\
\text { dobré sousedské } \\
\text { vztahy; emancipace } \\
\text { Německa } \\
\text { v mezinárodní politice; } \\
\text { mírové řešení } \\
\text { mezinárodních vztahů }\end{array}$ & $\begin{array}{l}\text { Snaha o ukotvení } \\
\text { etnické jednoty } \\
\text { Německa; země jako } \\
\text { předloha pro ostatní } \\
\text { státy (ve vybraných } \\
\text { oblastech); podpora } \\
\text { etnických menšin } \\
\text { žijících mimo } \\
\text { Německo; silná } \\
\text { německá marka }\end{array}$ & $\begin{array}{l}\text { Zmínka o podpoře } \\
\text { demokracie; role církví } \\
\text { při pádu komunismu }\end{array}$ \\
\hline
\end{tabular}

Zdroj: autor

Vertikální imperativ evropské integrace CDU lze spatřit $\mathrm{v}$ otázce obecného přístupu $\mathrm{k}$ evropské integraci jako nástroji ke smírení národů a kultur v Evropě. V kontextu dalšího vývoje CDU je poněkud překvapující, že v ostatních volebních programech se problematika evropské integrace neobjevuje $\mathrm{v}$ takto komplexní podobě. Zmínku o roli a síle německé marky lze vnímat jako substituci německé jednoty. Ačkoli volební program se takto jasně nezmiňuje, důraz kladený na roli národní měny - výrazně vyšší než jen pouhý platební prostř̌edek - napovídá o roli povědomí o ekonomické hodnotě německého hospodářství. ${ }^{8}$ Při pohledu na společenskou situaci, ve které probíhaly volby v roce 1990, je s podivem, nakolik byla upozaděna role deklarovaných hodnot společnosti. Kromě zmínky o pluralismu lze nalézt v programu pouze konstatování role církví (myšleno křest’anských) na revoluci v roce 1989. Tento fakt je o to zajímavější, že volby v roce 1990 je možné vnímat jako ty, u kterých lze očekávat vzletná (tradičnî) hodnotová zvolání vyplývající ze situace sjednocení Německa a role křest’anství, jež se podílelo na ukončení Studené války.

\section{Volebni program $1994^{9}$}

Jakkoli se volební program z roku 1990 mohl zdát jako dozvuk dominance západního Německa nad nově sjednoceným státem, následující manifest již zřetelněji reflektuje nové společenské

\footnotetext{
${ }^{8}$ Tento postřeh je cenný zejména z dnešní perspektivy, kdy se Německo pokouší nalézt náhražku v podobě společné unijní měny.

9 Při analýze následujících programů se primárně věnuji zaznamenaným změnám ve srovnání s předešlým volebním programem. $\mathrm{V}$ prípadě, že nedošlo k výraznému posunu, nevěnuji v analýze dané kategorii primární pozornost.
} 
problémy - nerovnoměrný ekonomický vývoj, hospodářská transformace východních spolkových zemí, rostoucí nezaměstnanost (Chvátal 2010: 35). To se nejzřretelněji projevuje vytvořením kategorie brozeb, která symbolizuje posun ve vnímání rozvoje společnosti. U ostatních kategorií dochází k postupnému rozpracování praktických politických kroků a místo prohlubování zásadních společenských otázek nastává posun do podoby reálných politických kroků. Tato tendence je nejvíce patrná u kategorie Evropa, $\mathrm{v}$ níž je ve srovnání s předešlým volebním programem rozvíjeno explicitní zdůraznění německé předlohy pro fungování unijní politiky a také uvědomění německých zájmů v evropské politice zejména v oblasti finanční náročnosti. Druhým zásadním bodem je širší definování hodnot společnosti směrem k občanské dimenzi.

Tabulka č. 2: Přehled priorit volebního programu v roce 1994

\begin{tabular}{|c|c|c|c|c|}
\hline Volební & \multicolumn{4}{|c|}{ Analytická kategorie } \\
\hline \multirow[t]{2}{*}{1994} & Evropa & Národ & Hodnoty/Společnost & Hrozby \\
\hline & $\begin{array}{l}\text { Podpora nadnárodní } \\
\text { integrace; } \\
\text { zdůrazňování role } \\
\text { Německa v EU a } \\
\text { NATO, výhodnost } \\
\text { pro Německo; } \\
\text { měnová unie na } \\
\text { modelu } \\
\text { Bundesbanky }\end{array}$ & $\begin{array}{l}\text { Role marky jako } \\
\text { identifikačního prvku } \\
\text { s národem; cizinec } \\
\text { narozený v Německu } \\
\text { není automaticky } \\
\text { Němcem; kultura jako } \\
\text { prvek národní jednoty; } \\
\text { reflexe problematiky } \\
\text { imigrace }\end{array}$ & $\begin{array}{l}\text { Tolerance; rovnost mužů } \\
\text { a žen; občanská } \\
\text { společnost }\end{array}$ & $\begin{array}{l}\text { Extremismus ve } \\
\text { východních částech } \\
\text { Německa; } \\
\text { nacionalismus }\end{array}$ \\
\hline
\end{tabular}

Zdroj: autor

V porovnání s programem z roku 1990 dochází k výraznému nárůstu zdůrazňování role Německa $v$ EU a nově i v NATO a zejména k podtrhnutí výhodnosti integrace pro Německo. V této otázce je evidentní trend, který sleduje Udo Zolleis (2008: 186), kdy v průběhu 90. let docházelo knahrazení hodnotového směřování EU ekonomickými tématy, př́padně $\mathrm{k}$ ekonomizaci otázek, které byly v minulosti považovány za hodnoty. ${ }^{10}$ Ty jsou v programu představeny jako pozitivní faktor pro německé hospodářství. Dalším zajímavým bodem je snaha o utvoření měnové unie podle modelu Bundesbanky. Zde se jedná o explicitní snahu o přenesení německých zvyklostí (kultury) na unijní úroveň. V programu dochází k první reflexi problematiky integrace imigrantů, což pro CDU znamenalo de facto první okamžik vymezení se vǔči této problematice. Posunem volebního programu z roku 1994 je explicitní zmínka jevů nebezpečných pro společenský rozvoj. CDU tak reaguje na sjednocující proces Německa, který byl zejména pro některé části NDR spojen s výrazným společenským a ekonomickým vykořeněním. Tento fakt potvrzuje uvedení (stále) komunismu jako hrozby a nové vlny extremismu v některých č́stech NDR, např. v Berlíně. V této souvislosti je zajímavá zmínka nacionalismu jako hrozby - podobně jako v programu z roku 1990 -, ačkoli v jiných částech programu je vnímání německé dominance a prospěšnosti výrazně vyšší než v roce 1990.

Při analýze volebního programu konceptem path dependency lze dospět k závěru, že posuny priorit ve volebním programu z roku 1994 vůči volebnímu programu z roku 1990 byly důsledkem

\footnotetext{
${ }^{10}$ Potvrzení této teze lze spatřit např. v bodě týkajícím se integrace hospodářských politik na úrovni EU.
} 
reflexe společenského a politického prostředí. Změny vnímání priorit tedy nebyly způsobeny institucionálním krizovým momentem, ale inkorporováním podnětů prostředí.

\section{b. Období krize 1998-2002, analýza volebních programů}

CDU se mezi lety 1990 a 2005 pokoušela znovu upevnit svůj ideový a hodnotový profil. Výsledkem tohoto poněkud nepovedeného procesu byla dominance ekonomických témat, které odsunuly problémy se směřováním CDU na „druhou kolej“ (Zolleis 2008: 238). Tento proces vyvrcholil právě v tomto období, a to za přispění následujících faktorů: ekonomické problémy a zvyšující se nezaměstnanosti zejména ve východní části země; tlak na proměnu podoby německé integrační a imigrační politiky a zejména dvou po sobě jdoucích volebních porážek v roce 1998 a 2002. ${ }^{11} \mathrm{~V}$ tomto období došlo také dvakrát ke změně předsedy strany. Po volební porážce v roce 1998 odstoupil z postu předsedy strany Helmuth Kohl. Na jeho pozici byl zvolen dlouholetý předseda frakce CDU ve Spolkovém sněmu Wolfgang Schäuble. Po propuknutí skandálu se skrytým financováním CDU následujícího roku z postu odstoupil. Na přelomu tisíciletí CDU procházela velmi nepř́ijemným obdobím a nebyla schopna nalézt sjednocující osobnost. Tento proces vyústil angažováním předsedy sesterské CSU Edmunda Stoibera, bavorského zemského předsedy, jako lídra CDU/CSU pro volby do Spolkového sněmu v roce 2002.

I přes původní pozitivní vyhlídky, strana ve volbách byla opět poražena SPD (Roth, Jung 2002). Jedním z hlavních důvodů porážky byla neoblíbenost bavorského politika v celoněmeckém kontextu. Tento fakt potvrzuje, že strana nebyla schopna vygenerovat silného kandidáta. Současně Stoiberovo angažování a užší spolupráce CDU a CSU (poprvé ve volbách strany vystupovaly s jednotným volebním programem) se promítly do volebního programu. ${ }^{12}$ Tento okamžik lze také chápat jako upozadění priorit CDU ve prospěch CSU v momentě, kdy se CDU pokoušela nalézt adekvátní odpověd’ na stranickou krizi. Užší spolupráce s CSU a s tím související intenzivnější vnímání konzervativních témat je zajímavé sledovat $\mathrm{v}$ kontextu celoněmecké debaty o integrační politice. $\mathrm{V}$ jejím rámci došlo $\mathrm{k}$ zásadnímu uvolnění pravidel pro získání německého občanství. S příchodem Angely Merkelové do čela CDU se strana pokouší o modernizaci nejen svých tradičních témat, ale také o proměnu chápání vztahu jedince a společnosti a samozřejmě také vztahu vưči církvím (Lau 2009: 169). ${ }^{13}$ Ukončení se časově shoduje s vyvrcholením německé integrační debaty a s tím související zásadní proměnou oficiálních postojů strany vưči integračním tématům.

Toto období lze chápat jako změnu či přerušení kontinuálního vývoje strany z hlediska vládní účasti, resp. vítězství ve volbách. Při použití konceptu path dependency lze tento vývoj interpretovat jako snahu o politickou změnu vedoucí k opětovnému vítězství ve volbách za situace, kdy strana vychází z vymezeného prostředí. Změnu programatiky tak lze interpretovat

\footnotetext{
${ }^{11}$ Problematika integrace imigrantů žijících v Německu byla velmi aktuálním tématem zejména v době koalice SPD a Zelených v letech 1998-2005, kdy došlo k uvolnění restriktivní imigrační politiky. Na počátku tisíciletí se také rozběhla intenzivní debata uvnitř CDU o postoji k imigrantům. Tento proces vyústil v pozitivní postoj CDU, který se naplno projevil během vlády s SPD v letech 2005-2009. Ačkoli v současné době CDU nevěnuje této problematice př́lišnou pozornost, již samotné přihlášení se k ,integrační zodpovědnosti“ znamenalo výrazný modernizační posun. Blíže k tématu Haug, Müssig, Stichs (2011) nebo Schulte (2011)

${ }^{12}$ Ačkoli se CDU a CSU těšily po nepopulárních reformách vlády SPD (zavedení programu Harz IV, spory premiéra Gerhara Schödera a ministra financí Oskara Lafonteina vedoucí k rozkolu ve vedení SPD) na slibnou výchozí pozici ve volebním klání, skandál s financováním CDU a neschopnost nalezení nástupce Helmuta Kohla odsoudily stranu ke druhému místu. Blíže k problematickým okamžikům voleb do Spolkového sněmu v roce 2002 a neúspěchu CDU/CSU ve volbách Roth, Jung (2002).

${ }^{13}$ Blíže k tématu vztahu politických stran k církvím např. Größbölting 2013 (60-65).
} 
jako řetězec událostí vycházejících nejen z reakce na měnící se kontext německé politiky, ale také ze změny institucionálního nastavení strany - např. v podobě užší spolupráce se sesterskou CSU.

\section{Volebni program 1998}

Porážka CDU ve volbách v roce 1998 znamenala nejen ukončení éry Helmuta Kohla v čele Německa, ale také vyhrocení vnitřních sporů uvnitř strany. Odstoupení Kohla z čela CDU bylo momentem ztráty silné osobnosti, která se mimo jiné pokusila o ukotvení křest’anských demokratů do širšího liberálně-konzervativního filozofického rámce (Hacke 2008). CDU byla nucena čelit nejen klesající popularitě a nově vyvstalým problémům sjednoceného Německa, ale také nutnosti nalezení nového hodnotového profilu strany. Z programu pro volby v roce 1998 je patrné, jakým způsobem se CDU pokouší definovat své ideové ukotvení. Souběžně strana opětovně zdůrazňuje národní zájmy a politickou a ekonomickou roli Německa. Tento posun je o to zajímavější, že ve srovnání s levicovými stranami se CDU posouvá do pozice, v níž prosazuje národní zájmy, resp. přenos německých politických návrhů na evropskou úroveň.

Tabulka č. 3: Přehled priorit volebního programu v roce 1998

\begin{tabular}{|c|c|c|c|}
\hline Volební & \multicolumn{3}{|c|}{ Analytická kategorie } \\
\hline \multirow[t]{2}{*}{1998} & Evropa & Národ & Hodnoty / společnost \\
\hline & $\begin{array}{l}\text { Vnímání národních zájmů; přenesení } \\
\text { německých best practicies na evropskou } \\
\text { úroveň; neúměrné finanční zatížení } \\
\text { Německa }\end{array}$ & $\begin{array}{l}\text { Deklaratorní pozitivní přístup } \\
\text { k cizincům, ale při nedodržování } \\
\text { podmínek - vyhoštění; zemědělství } \\
\text { jako rozvoj kulturlandschaft, kvalita } \\
\text { německých výrobků Made in } \\
\text { Germany }\end{array}$ & $\begin{array}{l}\text { Role církví ve } \\
\text { společnosti; rodina }\end{array}$ \\
\hline
\end{tabular}

Zdroj: autor

V analyzovaném volebním programu se kromě obecné podpory nadnárodní integrace výrazně projevuje proměna vnímání role Německa v EU. Je patrné, že étos roku 1990 byl vystrí́dán ekonomickou a politickou realitou a také úbytkem zájmu o striktně prosazovanou nadnárodní integraci v plně vertikální podobě - jako prevence vůči nacionalismu, upozadění národních cílů a prospěšnosti supranacionální politické podoby EU. Nyní je však zřejmé, že dochází k prosazování následujících dvou procesů: nárůstu vnímání národních zájmů a přenosu německého pohledu na fungování EU na unijní úroveň. První bod lze spatřit ve vnímání neúměrného finančního zatížení Německa vEU, což představuje ve srovnání s předešlými volebními programy výrazný posun. Druhým bodem je prosazování principu subsidiarity, což je jeden z klíčových prvků federálního uspořádání Německa, a podpora společné měny ve smyslu její podobné stability jako německá marka.

K zajímavému vývoji národních percepcí dochází v případě vztahu vůči v Německu žijícím menšinám. CDU sice deklaruje přátelskost vůči ciə̧incưm, ale současně stanovuje striktní mantinely ve vztahu k omezení prristěhovalectví a $\mathrm{k}$ imigrantům žijícím v Německu: v prípadě nerespektování stanovených podmínek - které ovšem v programu CDU nespecifikuje - mají být vyhoštěni. Tento př́stup je ve spojitosti s podporou etnických Němců znakem nepřipravenosti strany řešit společenskou situaci, jež výrazně ovlivňuje podobu německé společnosti. Posun vnímání jednoty Německa lze spatřit ve vztahu k zemědělství - CDU tuto oblast chápe nejen ve 
schopnosti zásobit Německo potravinami, ale také v uchopení venkova jako kulturlandschaft. Z podobné perspektivy lze hodnotit také zdůrazňování kvality německých výrobků a s tím související hrdost na německý průmysl ve formě sloganu Made in Germany. Při pohledu na tuto zmínku z perspektivy postupného upozad'ování zdůrazňování tradičních hodnot je nutné se tázat, z jakého důvodu CDU tyto hodnoty explicitně zmiňuje. Stejně tak je nutné vzít v úvahu tvrzení o respektování národních zájmů v obecném kontextu - tedy nejen ve vztahu k EU.

Při srovnání kategorie národ s volebními programy z let 1990 a 1994 je zřejmé, že dochází $\mathrm{k}$ postupnému nárůstu důrazu na vnější respektování národních zájmů a upevnění národní jednoty poněkud nepř́mými prostředky. ${ }^{14}$ Je však třeba dodat, že tyto změny souvisejí obdobně jako v prŕpadě volebního programu z roku 1994 s reflexí společenského kontextu a nejsou vyvolány vnitřní (institucionálnî) krizí. Tento vývoj je zajímavé sledovat právě v širším kontextu strany. V devadesátých letech dochází k postupnému upozad'ování vlivu křest’anské dimenze politiky - ačkoli nebyla nijak výrazně reflektována ani ve volebním programu v roce 1990 - a zároveň se v programech posiluje vnímání prosazování národních zájmů.

\section{Volebni program 2002}

Volby do Spolkového sněmu v roce 2002 lze v kontextu sledovaného období shledat jako zásadní moment pro formování národní, resp. evropské identity. V programu se objevují partikulární zmínky směřující např. vưči sudetským Němcům, což lze vnímat jako vliv účasti CSU na formování společného programu. Pro obecný kontext volebního programu je třeba také doplnit fakt, že CDU se v uplynulém období nacházela v opozici, a tudíž percepce evropských témat zachycuje snahu o opětovně silné postavení Německa v rámci EU (Jannig 2004: 312). Vliv CSU na zdůrazňování národních témat lze mimo jiné spatřit ve vztahu k zemi jako Vaterlandu, ve zdůraznění patriotismu a také v opětovném prohloubení důrazu vioči křest’anským tradicím.

Tabulka č. 4: Přehled priorit volebního programu v roce 2002

\begin{tabular}{|l|l|l|l|}
\hline $\begin{array}{l}\text { Volební } \\
\text { program }\end{array}$ & \multicolumn{3}{|c|}{ Analytická kategorie } \\
\hline 2002 & Evropa & Národ & Hodnoty/Hrozby \\
\hline & $\begin{array}{l}\text { Aktivní role Německa v EU; } \\
\text { zachování národních zájmů } \\
\text { v evropské politice; evropanství } \\
\text { jako součást integrace }\end{array}$ & $\begin{array}{l}\text { Emocionální Vaterland; zmínka } \\
\text { patriotismu; podpora sudetských } \\
\text { Němců; obezŕetný pŕístup } \\
\text { k imigrantům - musí se chtít } \\
\text { integrovat; němčina jako integrační } \\
\text { prvek }\end{array}$ & $\begin{array}{l}\text { Kŕest'anské hodnoty; Proti } \\
\text { náboženskému fanatismu }\end{array}$ \\
& & & \\
\hline
\end{tabular}

Zdroj: autor

Ve vnímání evropských témat je zřejmá snaha vymezení se vůči evropské politice vládní SPD a Zelených. Ve srovnání s předešlými volebními programy je kladen větší dưraz na znovunabytí výrazné a aktivní role Německa při integraci EU. Ačkoli je patrná podpora nadnárodní integrace, v programu se také zřetelně objevuje důraz na zastupování národních zájmů v evropské politice. Tato percepce navazuje na postupně zvětšující se důraz na zastupování, resp. prosazování národních zájmů. Proto tuto zmínku nelze vnímat bez kontextu předešlých volebních programů.

${ }^{14}$ Obdobně jako ve volebním programu z roku 1994 lze spatřit určitou formu „hledání“ (konzervativních) hodnot, které by odrážely realitu období po rozpadu východního bloku (Zolleis 2008). 
Nově se také objevuje uvádění evropanství jako jednoho z klíčových prvků integrace EU. $\mathrm{V}$ programu je poprvé zmíněna podpora rozšíření EU, a to nejen v deklaratorní rovině, ale rovněž coby historická šance pro EU. Současně se CDU vyslovuje proti vstupu Turecka do EU.

V programu z roku 2002 dochází k prosazení dvou hlavních tendencí. První z nich je emocionálnější prístup $\mathrm{k}$ národu ve formě Vaterlandu a podpoře patriotismu. Při pohledu na dř́vější volební programy je zřejmé, že dochází k postupnému lineárnímu nárůstu vnímání pojmu národní jednoty. Podporu sudetských Němců jako výrazné prohloubení zájmu CDU o oblast předválečného pobytu německého obyvatelstva, je nutné vnímat za situace, kdy CDU kandiduje společně s CSU. Zájmy bavorské CSU jsou v tomto ohledu tradičně citlivější než v př́padě CDU. Zajímavý vývoj zaznamenala CDU $\mathrm{v}$ oblasti př́stupu $\mathrm{k}$ imigračním otázkám, respektive $\mathrm{k}$ integraci menšin do německé společnosti. Př́stup CDU byl výrazně „,vycentrován“ a i přes velmi rezervovaný prístup $\mathrm{k}$ této problematice je patrná snaha o odmítnutí explicitního negativního postoje. CDU se staví velmi rezervovaně k multikulturnímu společenskému uspořádání. Ve vztahu k integraci cizinců používá výrazně umírněný slovník - ve vztahu $\mathrm{k}$ integrační schopnosti Německa je nutné přistupovat k rostoucímu počtu imigrantů obezřetně a zároveň imigranti musí projevovat zřetelný zájem o integraci do německé společnosti. CDU $\mathrm{v}$ tomto ohledu nabízí podporu výuky německého jazyka u imigrantů jakožto jednoho z hlavních integračních prvků.

Stranická krize CDU na přelomu tisíciletí byla sice vyvolána primárně vnitřními problémy strany. Nicméně změna na postu předsedy strany (W. Schäuble a následně A. Merkelová) společně se společenskými reformami realizovanými levicovou koalicí znamenaly pro CDU nutnost výrazné reformy. Z tohoto důvodu je zřejmé, že v programu z roku 2002 dochází $\mathrm{k}$ nejvýraznějším posunům oproti předešlému programu v celém sledovaném období. V tomto lze tvrdit, že strana výrazně reagovala na nejen na proměnu vnějšího kontextu, ale také na vlastní institucionální krizi. Ta mimo jiné způsobila nominování předsedy CSU Edmunda Stoibera na post kandidáta na kancléré, a tím pádem zvýšení vlivu CSU na vnímání národních oblastí programu.

\section{c. Období 2005-2009, analýza volebních programů}

Proces modernizace a přizpůsobení se konzervativní strany novým společenským trendům je možné spatřit např́klad ve zmínce bývalého prezidenta Christiana Wulfa (CDU) o vztahu islámu a Německa. Dle jeho teze je islám integrální součástí německé kultury, což je z pozice konzervativního politika zásadní prohlášení. Je zřejmé, že ve sledovaném období byla CDU nucena se „vyrovnat“ nejen s faktem, že Německo je přistěhovaleckou zemí, ale také s nutností inkorporace této proměny do svého profilu. ${ }^{15}$ Tento moment symbolizuje, nakolik byla CDU nucena uzpůsobit nejen svůj křest’anský profil, ale zejména i obecný vztah ke konzervativním hodnotám. ${ }^{16}$ Tento vývoj postoupil do podoby, kdy se CDU ve volebním období 2009-2013

\footnotetext{
${ }_{15}$ Podrobně se proměně vztahu CDU k islámu a imigrantům věnuje např. Lau (2009: 133-168).

${ }^{16} \mathrm{~V}$ období od konce 80 . let dochází k postupné proměně role a struktury dvou největších německých politických stran. Obě strany dlouhodobě čelí nejen úbytku svých členů, ale také zmenšujícímu se společenskému a hospodářskému významu. Německá sociální demokracie je tímto procesem výrazně více ovlivněna, což se odráží mimo jiné na nízkých volebních preferencích v uplynulých 10 letech. Ačkoli se CDU vypořádává s tímto procesem lépe - v pravo-středové části politického spektra se kromě CDU/CSU nachází pouze Freie Partei Deutschlands (FDP), kdežto v prŕpadě SPD se jedná o postkomunistickou Die Linke a o Zelené -, situace, kdy CDU byla hybnou silou politického a společenského života, na počátku 90. let pominula. CDU (avšak nejen ta) byla nucena nově definovat vlastní společenskou a politickou roli.
} 
pozitivně postavila $\mathrm{k}$ problematice právního rámce soužití osob stejného pohlaví, ${ }^{17}$ k problematice kvót pro ženy ve vysokých manažerských funkcích či podpory přistěhovalců směřujících do Německa s cílem zachování úrovně německé ekonomiky (Die Zeit 2013a). Pod vedením kancléřky Merkelové se CDU nachází v pozici nejsilnější politické strany na německé politické scéně a současně Merkelová nemá žádné relevantní vnitrostranické vyzyvatele. CDU velmi efektivně opanovala diskuzi nad budoucností evropské společné měny, čímž posílila také svou pozici na evropské úrovni (Clemens 2009: 127; Harnich 2009).

Snahou vedoucí k proměně institucionálního nastavení CDU bylo zahájení spolupráce s CSU při volbách do Spolkového sněmu. Z hlediska programových priorit dochází ve jmenovaném období k méně výrazným změnám než ve srovnání s obdobím 1998-2002. Ustálení vnímání národních priorit se vztahuje ke třem hlavním oblastem: $\mathrm{v}$ evropské politice dochází k výraznému vnímání národních zájmů; pozitivní pohled na problematiku integrace migrantů žijících v Německu; zdůrazňování křest’anského hodnotového uspořádání společnosti.

\section{Volebni program 2005}

Tento volební program lze ve srovnání se všemi předešlými definovat jako zásadní v procesu hodnotové a programové modernizace strany. CDU se po dvou neúspěšných pokusech o poražení SPD ujala pod vedením Angely Merkelové vedoucí role ve vládní koalici (společně s SPD). S postavou Angely Merkelové došlo $\mathrm{k}$ ukončení étosu éry Helmuta Kohla a jeho spolupracovníků. Výsledkem hledání nového hodnotového rámce byl pro CDU posun do výrazně středové pozice a s tím související menši důraz některých tradičních konzervativních témat. Na konci tohoto procesu byla výrazná proměna imigrační politiky, která se stala vůči cizincům výrazně prŕíznivější. Dalším znakem je obecně menší důraz na obecné jednotící snahy vedoucí k podpoře jednoty Německa. Tento trend je ovšem porovnatelný s ostatními politickými stranami a vypovídá nejen o proměně CDU, ale také o obecně menší roli ukotvujících hodnotových rámců pro společnost. Při porovnání s ostatními politickými stranami a jejich programy je evidentní úbytek ideologického a hodnotového rámce volebních programů. Tomuto trendu se musela přizpůsobit i CDU.

Tabulka č. 5: Přehled priorit volebního programu v roce 2005

\begin{tabular}{|c|c|c|c|}
\hline Volební & \multicolumn{3}{|c|}{ Analytická kategorie } \\
\hline \multirow[t]{2}{*}{2005} & Evropa & Národ & Hodnoty \\
\hline & $\begin{array}{l}\text { Pragmatické prosazování } \\
\text { národních zájmů v evropské } \\
\text { politice; ne vše, co nabízí EU, je } \\
\text { pro Německo pozitivní; princip } \\
\text { solidarity; posílení národních } \\
\text { parlamentů }\end{array}$ & $\begin{array}{l}\text { Kolektivní německá identita; hrdost } \\
\text { na Vaterland; německé hospodářství } \\
\text { jako prvek jednoty; Německo } \\
\text { otevřené a přívětivé vůči cizincům; } \\
\text { kultura součástí identity; Německo } \\
\text { kulturní národ }\end{array}$ & $\begin{array}{l}\text { Vágní podpora } \\
\text { křest'anských hodnot }\end{array}$ \\
\hline
\end{tabular}

Zdroj: autor

\footnotetext{
17 Ačkoli jsou svazky osob stejného pohlaví uzákoněny již od počátku tisíciletí, CDU zastávala spíše konzervativní postoj k posílení práv vyplývající z uzavřených svazků. Po březnovém (2013) rozsudku německého Spolkového ústavního soudu se ministr financí Wolgang Schäuble, který sám podobný krok dříve odmítal, vyjádřil k podpoře plnému zrovnoprávnění svazků osob stejného pohlaví. Více např. Die Zeit 2013b.
} 
V programu je zřetelný posun vnímání evropské politiky, a sice do roviny pragmatických politických návrhů, respektive př́stupů k evropským tématům. Volební program současně výrazně méně zdůrazňuje prosazování německých národních témat v procesu evropské integrace a evropské politiky. V souvislosti s výše zmíněným pragmatickým prŕstupem nejen k evropské politice lze sledovat, že normotvorná stránka EU nemusí být vždy přijímána pozitivně, resp. považována za Německu škodící. Posílení pragmatické pozice Německa v rámci unijní politiky se dále projevuje tradičními evropskými tématy CDU: zdůrazňováním principu solidarity, zapojením národních parlamentů do legislativního procesu a opětovným definováním role Německa jako silného partnera $\mathrm{v}$ EU. Ve srovnání s předešlými volebními programy nedochází $\mathrm{k}$ explicitnímu zmiňování prosazování národních zájmů, CDU chápe roli Německa jako silného partnera v EU.

Podobně jako v př́padě volebního programu z roku 1990, který byl výrazně rozkročen mezi etickou jednotu a supranacionální integrační imperativ, dochází ve volebním programu v prosazování kolektivní německé identity i ve formě hrdosti na Vaterland a současně dochází $\mathrm{k}$ výrazné proměně integrační a imigrační politiky. První část je možné vztáhnout na snahu CDU klást důraz na hrdost na zemi a prostř̌ednictvím německého hospodářství kolektivně uchopit identitu země, což je výrazný posun i ve srovnání s dobou kolem sjednocení Německa na počátku analyzovaného období. Druhou částí je proměna integrační politiky. Zde lze sledovat vyvrcholení procesu modernizace CDU, nebot' se strana nejen vyslovuje pro podporu integrace migrantů, ale definuje Německo jako světu otevřenou zemi a př́větivou vưči cizincům. Tento fakt lze $\mathrm{v}$ porovnání s postoji $\mathrm{v}$ předešlých volebních programech shledat jako výrazný modernizační krok. Další částí definující národní kategorii a značící proměnu vnímání otázek týkajících se identit je role kultury (resp. její přesah) jako základního prvku národní identity. CDU definuje Německo jako kulturní národ a v současné době vidí kulturu jako nedílnou součást identity.

Vzhledem k volebnímu vítězství a upevnění role CDU na německé politické scéně lze říci, že vnitrostranické změny CDU byly úspěšné. Vedly nejen k volebnímu vítězství, ale také $\mathrm{k}$ upevnění pozice v rámci stranického systému. Stejně tak neúspěch ve volbách v roce 2002 se projevil nejen změnou na postu kandidáta na kanclére, ale také upozaděním emocionálních prvků programu. Podobně jako v př́padě roku 2002, institucionálně proměna strany vyvolaná volebním neúspěchem (krizî) způsobila změnu vedoucí k volebnímu vítězství.

\section{Volebni program 2009}

Poslední analyzovaný volební program je možné vnímat jako referenční rámec pro pokračování vývoje zkoumaných percepcí. Účast ve vládní koalici znamenala pro CDU umírnění prosazování konzervativnějších témat a vzhledem $\mathrm{k}$ postupnému završení procesu modernizace se výrazně etablovala ve středu politického spektra. Strana zaznamenala velký úspěch při zapracování témat politických konkurentů do svého programu zejména v sociální oblasti. Tím se CDU stala do značné míry hybatelem ideologického sbližování parlamentních politických stran (Göhs 2013). Dále je nutné vzít v úvahu rozsah hospodářské krize, který se nejvýrazněji prosadil v roce 2009. Při pohledu na volební programy pro uplynulá volební období se dá předpokládat, že způsob percepce témat naváže na minulé programy.

Vzhledem k obecnému trendu dominance pragmatických témat $\mathrm{v}$ německé politice a postupnému ideologickému sbližování jednotlivých politických stran je poněkud překvapivé, do jaké míry došlo ve volebním programu $\mathrm{k}$ nárůstu emocionálního zabarvení zejména hodnotové části volebního programu. Tento posun je zajímavý zejména ve srovnání s ostatními politickými stranami a jejich volebními programy, u kterých nastala naprosto opačná tendence. 
Tabulka č. 6: Přehled priorit volebního programu v roce 2009

\begin{tabular}{|c|c|c|c|}
\hline Volební & \multicolumn{3}{|c|}{ Analytická kategorie } \\
\hline 2009 & Evropa & Národ & Hodnoty \\
\hline & $\begin{array}{l}\text { Efektivní prosazování } \\
\text { národních zájmů v EU; přenos } \\
\text { německých zvyklostí v rámci } \\
\text { EU; posílení NJ v EU; ECB } \\
\text { řízena na základě stejných } \\
\text { pravidel jako Bundesbanka; ne } \\
\text { všechna nařízení EU jsou pro } \\
\text { Německo výhodná }\end{array}$ & $\begin{array}{l}\text { Kolektivní německá identita; } \\
\text { hrdost na Vaterland; německé } \\
\text { hospodářství jako prvek } \\
\text { jednoty; Německo otevřené a } \\
\text { přivětivé vǔči cizincům; kultura } \\
\text { součástí identity; Německo } \\
\text { kulturní národ; plná integrace } \\
\text { cizinců do společnosti; sloužit } \\
\text { zemi v těžkých časech jako } \\
\text { celku; vytváření lásky k } \\
\text { domovině }\end{array}$ & $\begin{array}{l}\text { Křest’anství jako hodnotové } \\
\text { uspořádání německé } \\
\text { společnosti; } \\
\text { společenská/individuální } \\
\text { zodpovědnost před Bohem; } \\
\text { islám součástí německé } \\
\text { společnosti }\end{array}$ \\
\hline
\end{tabular}

Zdroj: autor

V prrípadě témat věnujících se evropské politice je zřetelný opětovný posun směrem k prosazování a efektivnímu zastupování národních zájmů. Tento trend je patrný nejen hlubším rozpracováním představ o prosazování národních zájmů, ale také explicitně zmíněnou transkripcí německých politických a společenských zvyklostí do prostředí EU. Konkrétně se jedná o přenos právního rámce německého hospodářství na unijní úroveň, zdůrazňování role sociálně-tržního hospodářství a v poslední raadě také o posílení německého jazyka v EU. Za zmínku také stojí vnímání Evropské centrální banky, která by měla být dle CDU řízena stejnými pravidly jako německá Bundesbanka. ${ }^{18}$ Při analýze nelze opomenout v programu chybějící explicitní zmínku o podpoře nadnárodní integrace EU, jako tomu bylo v předešlých volebních programech.

Ve srovnání s předešlými volebními programy dochází v kategorii národ ke dvěma paralelním procesům. Prvním z nich je stále se umírňující prrístup k imigrační problematice, tím druhým je zř̌etelně deklarovaná snaha o integraci imigrantů do německé společnosti. Právě v tomto bodě dochází ke spojení snahy o kulturní sjednocení. Role znalosti německého jazyka (v obecném kontextu) je vnímána společně s reálnou snahou o komplexní integraci společnosti jako formy identifikace se společností, ve které žijí. Tento směr je doplněn o zdůraznění praktických kroků, mezi něž lze zařadit podporu kvalifikované imigrace do Německa a obecně konstruktivní vyư̌ití migrantů. Zároveň $\mathrm{v}$ percepci národních témat dochází $\mathrm{k}$ opětovnému důrazu na lásku $k$ domovinè a $\mathrm{k}$ podpoře pozitivního vztahu $\mathrm{k}$ Německu.

V prrípadě vnímání hodnot dochází k výraznému posunu vnímání křest’anství. CDU jej definuje jako základ hodnotového uspořádání společnosti, zdůraznění role křest’anských církví v občanské společnosti, přičemž se zajímavě zmiňuje o společenské/individuální odpovědnosti před Bohem. Nejedná se pouze o uvedení tradičních hodnot nebo role náboženství, ale o transformace jeho role v sekularizované společnosti. Důležitou zmínkou volebního programu je také islám jakožto součást německé kultury. Tento fakt svědčí o snaze CDU reflektovat společenský vývoj a rozvíjet svưj konsensuální potenciál prezentovaný zejména Angelou

${ }^{18} \mathrm{~V}$ této souvislosti nelze ironicky nedoplnit, že tato zmínka působí jako předzvěst unijních měnových problémů. Je nicméně velmi pozoruhodné, že tato percepce je uvedena deset let po zavedení společné měny. 
Merkelovou. Schopnost zapracovat do programu strany vnější impulzy se stalo i hlavním důvodem pokračování úspěšné éry Angely Merkelové. Z hlediska použitého analytického rámce je nutné zdůraznit, že vliv kontextu (prostředî) na utváření politických priorit se stal typickým znakem úspěchu Angely Merkelové v čele CDU.

\section{Zhodnocení vývoje percepcí CDU}

Zajímavým jevem je postupný nárůst vnímání německého způsobu politiky a zvyklostí jako ideálního nástroje pro přenos na evropskou úroveň. Tento trend je evidentní v postoji $\mathrm{k}$ Euru $\mathrm{v}$ linii vztahu Německa $\mathrm{k}$ marce, tvorbě měnové unie a snaze o identifikaci s novou měnou - je zřejmé, nakolik je pro CDU zásadní společná měna jako prvek identifikace s hospodářskou a politickou dimenzí EU a jak je souběžně obtížné opuštění jednoho ze znaků úspěšného poválečného rozvoje země.

Dalším bodem je proměna přístupu $\mathrm{k}$ imigrantům a integračním tématům obecně. Je patrné, že strana byla nucena $\mathrm{v}$ rámci procesu modernizace akceptovat společenskou situaci a inkorporovat tato témata do svého programu. Nejedná se však pouze o jejich zahrnutí, ale také o postupně pragmatický (akceptujícî) prrístup $\mathrm{k}$ této problematice - začlenění imigrantů do německé společnosti a současně odmítání tvorby paralelních společností. Z pohledu prístupu k imigračním tématům se nabízí zajímavé srovnání s podporou návratu etnických Němců ze zahraničí, ve které lze spatř̌it výrazný homogenizační apel CDU. Ve vnímání vztahu ke společenskému celku dochází ke kontinuální snaze o podporu kultury jako identifikačního prvku jedince se společností. Třetí částí, která symbolizuje vývoj CDU ve zkoumaném období, je otázka vnímání hodnot a jejich role ve společnosti. Podobně jako v prŕpadě evropské politiky dochází ke kontinuální snaze o uchopení křest’anství jako hodnotového rámce pro společnost. Tento trend je pozoruhodný ze dvou hledisek - v rámci procesu postupující sekularizace se jedná o de facto protichůdný směr rozvoje; výsledkem procesu modernizace CDU je výrazněǰši percepce křest'anských témat $\mathrm{v}$ porovnání s počátkem sledovaného období. Tento fakt lze považovat za zajímavý modernizační výsledek, a to v souvislosti, kdy se strana jako celek výrazně přesunula do středu politického spektra. Jedním z vysvětlení může být společný volební program CDU a CSU. Bavorská CSU se v těchto tradičních konzervativních tématech profiluje výrazně více než CDU.

Při pohledu na proměnu vnímání národní jednoty mezi obdobím 1990-1998 a následujícím od roku 1998 do 2002 je zřejmé, že ekonomická situace Německa (v tomto smyslu prostředî) a institucionální problémy (z hlediska hledání nových politických priorit) byly významným faktorem při formulování národních percepcí CDU. Ačkoli nelze vysledovat zásadní zlom, proměnu vnímání národních zájmů ve vztahu $\mathrm{k} E U$ a snahu o definování jednotících prvků německé společnosti lze chápat jako reakci na proměnu vnějšího prostředí; jinými slovy, vnější prostředí působilo jako počáteční krizový moment vyvolávající proměnu politiky. V souvislosti s hospodářskými problémy strana kromě praktických politických kroků reaguje snahou o posílení národní jednoty, což lze vztáhnout na první výzkumnou otázku. Volební program pro volby v roce 2002 nevykazuje ve srovnání s rokem 1998 zásadní zlom, spíše lze vysledovat počátek dlouhodobějšího trendu.

Při použití konceptu path dependency na vývoj národních percepcí lze sledované období rozdělit do následujících fází. V období do roku 1998 dochází pouze k dílčím změnám, které reflektují vývoj prostředí, ve kterém se aktér pohybuje. Nicméně souběh politických a institucionálních změn v období od roku 2002 do roku 2005 lze označit jako počátek stabilizace strany v poslední dekádě. V tomto smyslu krize CDU (v období 1998-2002) znamenala proměnu 
vnímání národních priorit $\mathrm{v}$ reflektující proměňující se kontext německé politiky a stejně tak projekci vlastních pozměněných priorit. Při bližším pohledu na proměnu priorit CDU se nabízí zajímavý obrázek, který dostal jasné kontury v poslední části sledovaného období (2005-2009). Jedná se o přizpůsobení se německého politického a společenského kontextu v oblasti imigrace. Zde se CDU výrazně přizpůsobila politice ostatních relevantních stran. Z velmi vlažného postoje k cizincům žijícím v Německu se posunula $\mathrm{k}$ relativně inkluzivnímu mainstreamu německé debaty o budoucím etnickém uspořádání. Druhým bodem je postupná proměna evropské politiky. CDU postupně opustila neochvějnou podporu nadnárodní integrace. Ta byla nahrazena reflektováním vlastních národních zájmů a snahou o přenos německých principů na evropskou úroveň. V tomto ohledu se jedná o protichůdný vývoj oproti levicovým stranám německé politiky, které v současné době tvoří hlavní podporovatele nadnárodní integrace zejména $\mathrm{v}$ její občanské rovině. Ve srovnání s imigrační politikou nelze hovořit o přizpơsobení se kontextu německé debaty, ale o projekci vlastních programových priorit. Tento trend je postupně viditelný v programech od roku 1998. Lze potvrdit, že krize (roku 1998) vyvolala změnu institucionálních a politických priorit, která byla v delším časovém horizontu úspěšná (vítězství ve volbách v letech 2005 a 2009). Strana dokázala úspěšně inkorporovat změnu kontextu politiky a současně krizové období využít pro v jednotlivých programech řetězící se proměnu evropské politiky.

Při zodpovězení druhé výzkumné otázky lze naopak vysledovat dynamiku podporující spíše deterministický prŕstup $\mathrm{k}$ path dependency, resp. Pailerovu argumentaci. Další výrazný posun ve vnímání otázek spojených s formováním národní identity (např. postoj k integrační politice nebo prosazování národních zájmů) nastává v následujících volebních programech (2005 a 2009). Ty zdůrazňují posílení národní jednoty a jednotících hodnot ve společnosti ve větší míře než programy v krizovém období 1998-2002. Lze tedy dospět k závěru, že k proměně ( $\mathrm{v}$ tomto případě posílení národních percepcî) není krize bezpodmínečně nutná, proměna může být tedy iniciována na základě vlastní institucionální struktury. Vezmeme-li v potaz dvě po sobě jdoucí volební vítězství, lze použitím Piersonovy argumentace dospět k závěru, že z počátečního krizového momentu vyšla CDU posílena.

\section{Bibliografie}

Poznámka: Elektronické zdroje byly zkontrolovány k 15. 2. 2014.

Banchoff, Thomas (1999): German Identity and European Integration, European Journal of International Relations 5.3, s. $260-284$.

Baumann, Rainer (2007): Deutschland als Europas Zentralmacht, in Siegmar Schmidt, Gunther (eds.) Power in the Global Age. Cambridge: Polity Press.

Breuilly, Jeffery (1993): Nationalism and the State, Manchaster Univesity Press, second edition Castells, Manuel (2010): The Power of Identity, Wiley-Blackwell, second edition Hellmann, Reinhard Wolf (eds.): Handbuch zur deutschen Außenpolitik, Wiesbaden: VS Verlag für Sozialwissenschaften.

Clemens, Clay (2009): Modernisation or Disorientation? Policy Change in Merkel's CDU, German Politics, 18: 2, s. 121 - 139. DOI: 10.1080/09644000902870859

Decker, Frank (2006): Die populistische Herausforderung. Theoretische und ländervergleichende Perspektiven, in: Decker Frank Populismus. Gefahr für die Demokratie oder nützliches Korrektiv?, Wiesbaden 2006, s. 9-31.

Ebbinghaus, Bernhard (2005): Can Path Dependence Explain Institutional Change? Two Approaches Applied to Welfare State Reform. MPIfG Discussion Paper 05/2. Max-Planck-Institut für Gesellschaftsforschung, Köln. 
Fetzer, Thomas (2009): Beyond Convergence versus Path Dependence: The Internationalization of Industrial Relations at Ford Germany and Britain (1967-1985), MPIfG Working Paper 09/3

Göhs, Olaf (2013): Osobní rozhovor provedený dne 25. 1. 2013

Großötting, Thomas (2013): Der verlorene Himmel, Bundeszetrale für politische Bildung, 1327.

Habermas, Jürgen (2006): Opening up Fortress Europe. Jürgen Habermas on Immigration as the Key to European Unity, dostupné na http://www.signandsight.com/features/1048.html.

Habermas, Jürgen (2010): Das utopische Gefälle. Blätter für Deutsche und Internationale Politik, 8, s. 4353.

Hacke, Jens (2006): Philosophie Der Bürgerlichkeit, Vandenhoeck\&Ruprecht, München

Harnisch, Sebastian (2009): The Politics of Domestication: A New Paradigm in German Foreign Policy, German Politics, 18: 4, s. 455-468

Haug S., Stichs A, Müssig S. (2009): Muslimisches Leben in Deutschland. Im Auftrag der Deutschen Islam Konferenz. Forschungsbericht. Nürnberg: Bundesamt für Migration und Flüchtlinge. Forschungsbericht Nr. 6.

Christlich Demokratische Union (1990): Ja zu Deutschland - Ja zur Zukunft"

Christlich Demokratische Union (1994): "Wir sichern Deutschlands Zukunft"

Christlich Demokratische Union (1998): Wablplattform

Christlich Demokratische Union (2002): Leistung und Sicherheit. Zeit für Taten

Christlich Demokratische Union (2005): Deutschlands Chancen nutzen. Wachstum. Arbeit. Sicherheit

Christlich Demokratische Union (2009): Wir haben die Kraft - gemeinsam für unseres Land

Chvátal, Filip (2010): Transformace ekonomiky východního Německa (Geografická analýza): Masarykova univerzita, Brno

Jannig, Josef (2004): Deutschland, in Weidenfeld W., Wessels W. (2004): Jahrbuch des Europäische Integration, IEP Berlin. Nomos.

Jöresen, Mathias a Zirfas Jörg. (2010): Schlüsselwerke der Identitätsforschung, Wiesbaden: Verlag für Sozialwissenschaften.

Kunštát, Miroslav (2011): Transformace německé historické paměti a její místo v zahraničněpolitické kultuře SRN, in: Vladimír Handl (eds.): Německo v čele Evropy? SRN jako civilní mocnost a hegemon eurozóny, Praha: Ústav mezinárodních vztahů, s. 92-118

Lochocki, Tim (2012): Immigrationsfragen als Sprungbrett rechtspopulistischer Parteien. In: Aus Politik und Zeitgeschichte B 5-6/2012, s. 30-36.

Mahoney, John (2000): Path Dependence in Historical Sociology, in: Theory and Society 29, s.507-548.

Maull, Hans W. (1999): Germany and the Use of Force: Still a Civilian Power?, N 2/1999, Universität Trier.

Maull, Hans W. (2007): Deutschland als Europas Zivilmacht, in Siegmar Schmidt, Gunther Hellmann, Reinhard Wolf (eds.): Handbuch zur deutschen Außenpolitik, Wiesbaden: Verlag für Sozialwissenschaften.

Max-Planck-Institut für Gesellschaftsforschung, Köln.

Müller, Gerta (2007): Deutsche Europapolitik, VS, Wiesbaden.

Pailer, Bruno (2008): A Long Goodbye to Bismarck?, Amsterdam: Amsterdam University Press.

Pickel, Susane (2011): Secularization of Electoral Behavior? The State-Church-Cleavage in Europe. In: Pickel, Gert/Sammet, Kornelia (eds.): Transformations of Religiosity. Religion and Religiosity in Eastern Europe 1989-2010. Wiesbaden: Verlag für Sozialwissenschaften, s. 111-134

Pierson, Paul (2000): Incerasing Returns, Path dependence, and the Study of Politics, The American Political Science Review, Vol. 94, No. 2, s. 251 - 267. DOI: 10.2307/2586011 
Pierson, Paul (2004): Politics in Time, Princeton and Oxford: Princeton University Press

Risse, Thomas (2002): Constructivism and International Institutions. Toward Conversations Across

Paradigms, in Katznelson Ira /Milner Helen (eds.), Political Science as Discipline. Reconsidering

Power, Choice, and the State at Century's End, New York, Norton, 597-623.

Risse, Thomas (2007): Deutsche Identität und Außenpolitik in Siegmar Schmidt, Gunther Hellmann,

Reinhard Wolf (eds.): Handbuch zur deutschen Außenpolitik, Wiesbaden: VS Verlag für

Sozialwissenschaften.

Risse, Thomas (2010): A Community of Europeans?: Transnational Identities and Public Spheres, Cornell University Press

Roth, Dieter a Jung, Matthias (2002): Ablösung der Regierung vertagt: Eine Analyse der Bundestagswahl

2002, dostupné na http://www.bpb.de/apuz/26565/abloesung-der-regierung-vertagt-eine-analyseder-bundestagswahl-2002? $\mathrm{p}=$ all

Scheuer, Agelika a Schmitt, Herman (2009): Sources of EU Support: The Case of Germany, German Politics, 18: 4, s. 577 - 590. DOI: 10.1080/09644000903349416

Schmidt, Manfred (2007): Das politische System Deutschlands, Bundeszentrale für Politische Bildung, 551

Schöpflin, George (2000): Nations, Identity, Power, London: Hurst \& Company

Schulte, Alex (2011): Integrationspolitik in der Bundesrepublik Deutschland: Von politischer Opportunität und institutionalisierter Ungleichbehandlung zur menschenrechtsbasierten Politik? Zeitschrift für Public Policy, Recht und Management Heft 1/2011, s. 29-60

Zeit Die (2013a): Ein Parlament voller Frauenversteher, dostupné na http://www.zeit.de/politik/deutschland/2013-04/frauenquote-cdu-gruene-merkel-leyen-kommentar Zolleis, Udo (2003): Die Organisationsentwicklungen in der Parteigeschichte der CDU, in Civis mit Sonde 3-4/03, S. 15-19

Zolleis, Udo (2008): CDU, Wiesbaden: Verlag für Sozialwissenschaften

\section{Analysis of the Development of the CDU's Perception of National Identity Between 1990 and 2009}

\section{SUMMARY}

The paper deals with the perception of the term national identity in the case of the German conservative party, the CDU. The analysis focuses on the time period from 1990 till 2009 using the path dependency concept. The main aim of the text is to focus on the development of national identity perception taking into account the process of European integration and the changing German societal environment. The paper deals chronologically with general elections held within the research period.

The paper aims to explain the development of the perception of national identity of the Christian Democratic Party (CDU), the strongest German political party over the past decade. The paper focuses on election manifestos for general elections in the 1990, 1994, 1998, 2002, 2005, and 2009 elections. To do so, each manifesto is divided into up to five analytical categories - such as values, nation, Europe, threats, and society. These categories aim to explore the party's perception in a wider context instead of focusing only on direct references to national identity.

For the purposes of this paper, the concept of path dependency was employed. This concept allows us to focus not only on perceptions as such from a structural/institutional perspective. Indeed, although, the path dependency concept is usually used to analyse institutional change (see e.g. Pailer 
2011, Pierson 2000 and 2004, or Ebbinghaus 2005), the paper employs this concept with respect to policy change. The paper does not focus on the role of the party's changing institutional setting. Nevertheless, the paper explains policy shifts in the context of institutional crisis that contributed to greater policy change. In addition to this, each chapter deals with the political context of the time period. It must be noted that the election manifesto is understood in this context as a shaping tool: political parties use the manifesto as a means of spreading their views; at the same time, the parties perceive the current state of society and, according to this, they adapt their policies or general perceptions.

To gain a complex picture, one has to consider the German political and societal environment: in this case, the relation between the national and European perceptions of national identity and the generally not often reflected research on national identity. Although scholars like Thomas Risse, Jürgen Habermas, and Hans Haull have contributed to this topic in their work, the perception of national identity has not been a significant topic of research.

The analysed period was divided into three phases with an emphasis on the internal crisis between 1998 and 2002. As argued, this crisis influenced policy priorities as well. In addition, the perceptions of elements belonging to the concept of national identity changed in order i) to gain victory in the general election in the 2002 and 2005, and ii) to reflect properly the state of German society. Therefore, significant policy shifts were made.

One can divide the analysis into the following parts: (i) the changed national identity perception as such, and ii) the crisis as the impulse for policy change. From the perspective of the six analysed elections, the changes in the perception of national identity are evident. Although the party stresses openness towards immigrants and the modernity of the nation as such, the manifestos tend to focus on the utilisation of tried and tested German practices at the EU level or the richness of German economic, cultural, and societal traditions like a strong national currency. In the context of European policy, this difference should be analysed in relation to the European debt crisis; it is evident that the existence of a strong German identity is a result of long term development. Nevertheless, this trend can be also observed in other political parties. In addition, this shift was followed by a weakening of the commitment to the European integration. Interestingly, the mention of ideas relating to national identity has become more evident in the last three analysed manifestos. However, the mentions of values or Christianity have become less important.

Employing the concept of path dependency elicits interesting findings. Defeat in the 1998 election caused a deep internal crisis, which lasted until 2002. In this case, the defeat was followed by a financial scandal. The party had to face two significant challenges at the same time: the creation of a new programmatic self-definition and overcoming the financial scandal. If one considers the time period from 1998 to 2002 as a preparatory period for the next general election, the institutional crisis which culminated in the appointment of Edmund Stoiber, the CSU former leader, as a chancellor candidate was not surprising. Nonetheless, in contrast to the 2005 election manifesto, the policy dimension did not change so significantly. The 2005 election manifesto can be perceived as a conclusion of the crisis phase from both an institutional and policy perspective. There was greater emphasis on ideas relating to national identity, such as German culture, German good practices transferred to the rest of the EU, and enforcing and defending German national interests in the EU. Nevertheless, the 2005, as well as the 2009 election victories showed that the internal crisis has been successfully overcome. Besides changing personal and institutional settings, the crisis had a significant influence on the policy dimension. The policy change shows how the party successfully integrated societal demands and preferences over the past decade. Thank to this, the CDU incorporated both 
conservative and liberal elements. This is evident in the case of incorporating liberal elements such as homosexual partnerships while, at the same time, actively stressing the importance of defending national interests. If one looks at this process from a wider perspective, the party followed left-wing parties in the sense of stressing the liberal values of the German society. This is most evident in the case of the 2005 election manifesto. 